\title{
CHANGING SCENARIO OF LIVESTOCK IN SELECTED DISTRICTS OF RAJASTHAN
}

\author{
Om Prakash \\ Assistant Professor, Department of Geography, JNV University Jodhpur (Rajasthan) \\ Email: oprjnvu@gmail.com
}

\begin{abstract}
Livestock population and productivity is greatly influenced by climatic conditions. The climate has a significant impact not only on cattle but also on other livestock. Along with climate livestock are also get influenced by the availability of good soil/land and rainfall supply. Rajasthan is a state of fluctuating local distinctiveness of land and climate. The cattle population of Rajasthan shows variations in different districts. As per the reports, Rajasthan and other parts country display poor livestock production. This article analyses the livestock of Total three districts with the help of study of total livestock available in these districts in different years since 1961 to 2012 including all the data for separate districts. The data is collected for different livestock that includes Cattle, Buffalo, Sheep, Goat, Horses \& Ponies, Donkey, Camel and others.
\end{abstract}

\section{Introduction}

The rural population of India consists of more than 70 percent. Hence, probably land is pressurized more as almost the entire village population relies on agriculture, resulting in an unfavorable landman ratio. Merely agriculture cannot provide gainful employment to all the rural areas as the population is exploding resulting in the increasing pressure on land. Thus, allied activities like animal husbandry can be considered as an effective instrument for supplementing the income and providing employment to the weaker sections in rural areas. Domesticated animals are prominently known as "live banks", are the significant contributors to our national wealth and therefore help in enhancing the living standards of rural people. The livestock population in Rajasthan has increased from 255.16 lacs in 1951 to 577.32 lacs; about 11.27 percent of Livestock population of country is available in Rajasthan". In this way animal husbandry remains the Prime occupation in Rajasthan. $19^{\text {th }}$ Enumeration of livestock was done in 2012 when the number of total domestic animal found to be 577.32 lacs and their density was 169 per sq. km. livestock sector provide consistent growth rate of over 6 percent per annum round the year employment opportunity with more than 50 percent of total house hold income in arid region as against national average of 22.5 percent and produce 11 percent milk, 30 percent wool and10 percent meat of the country. Rajasthan has Rank $1^{\text {st }}$ in wool production, Rank $1^{\text {st }}$ in live meat animals (goat, sheep, and buffalo) to the tune of about 40,000 heads per day Rank $2^{\text {nd }}$ in milk production in country more than 80 percent rural households keep animals which continue to provide subsistence income during scarcity.

In the arid and semi-arid zone livestock rearing is the primary occupation and the principal source of livelihood for the people and is only next to agriculture in importance. The study area (Jodhpur, Barmer and Nagaur Districts) is main part of this zone and has 12.60 percent of Rajasthan's total livestock. Barmer is one of leading district in having largest number of sheep (14.04lacs) goats (28.96 lacs), Horses (2591), donkeys and pony (17495), camels (43172) and total livestock (53.66lakh) according to $19^{\text {th }}$ livestock census 2012 . Study area is comparatively dry, rainless, hot and water scarcity area due to which the animal which can either survive on small quantity of water like sheep goats or prolong their life cycle for a longest period without water like camels and donkeys, livestock is the major source of livelihood for study area.

\section{Study Area}

The study area includes - Barmer, Jodhpur and Nagaur districts located between $24^{\circ} 58^{\prime}$ and $27^{\circ} 40^{\prime}$ North latitude and $70^{\circ} 5^{\prime}$ and $75^{\circ} 15^{\prime}$ East longitude. The study area is bounded on the north by Churu and Bikaner districts on the east by Sikar, Jaipur and Ajmer districts, on the south by Pali, Jalore districts and Gujrat state and on the west Jaisalmer district. The total geographical area of study area is 68,955 square kilometre. 


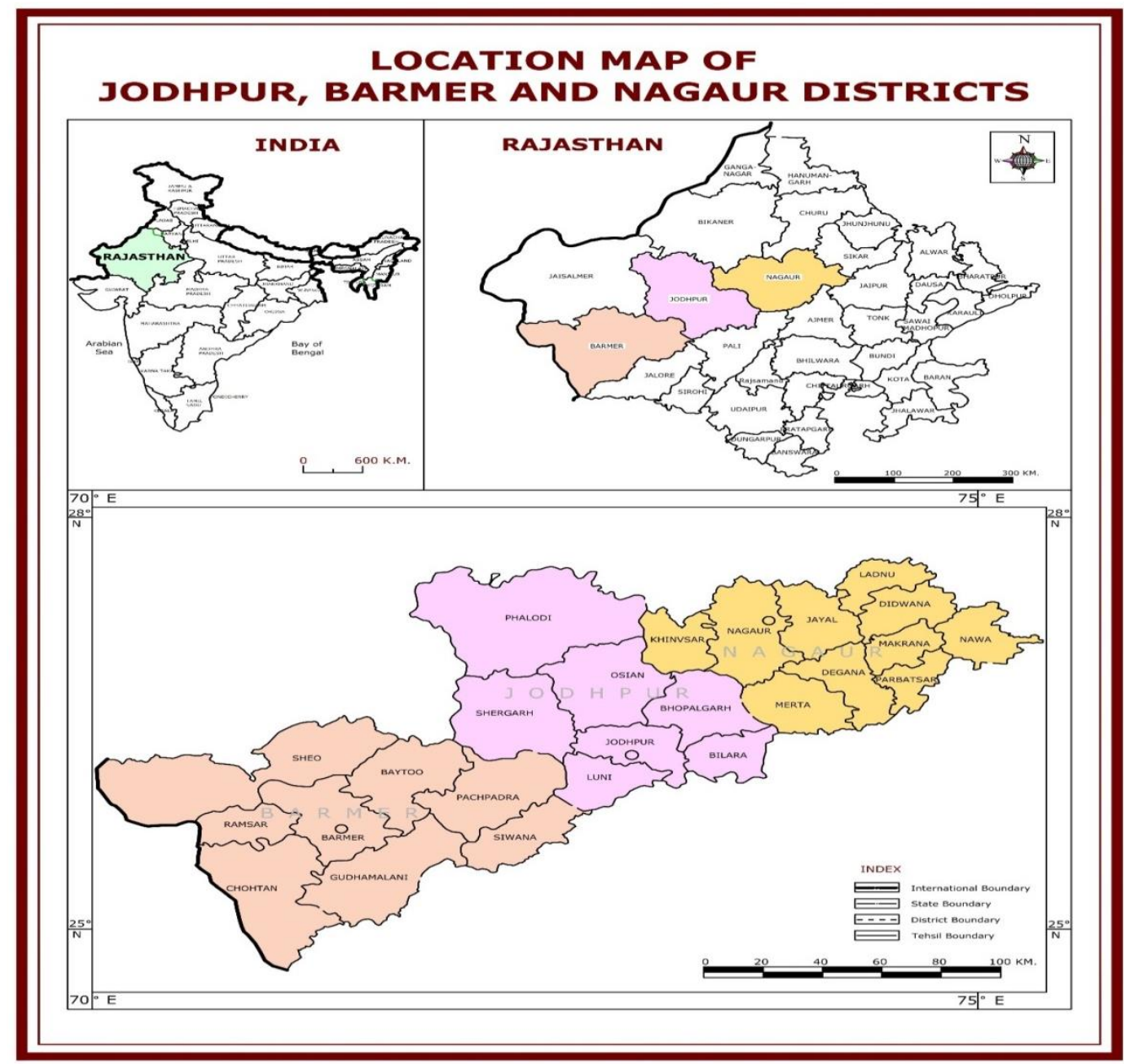

\section{Present Scenario of Livestock}

Rajasthan is majorly driven by the Service sector but farming and allied activities are still major sources of livelihood in villages. Livestock is the primary vocation of Rajasthan as 61.1 percent of the aggregate area is desert. The $19^{\text {th }}$ Livestock census, 2012 (GOI, 2014) stated that one of the biggest livestock in the world is that of India with a holding of 11.6 percent of world livestock population which consists buffaloes (57.83 percent), cattle (15.06 percent), sheep (7.14 percent), goats (17.93 percent), camel (2.18 percent), equine (1.3 percent), pigs (1.2 percent), chickens (4.72 percent) and ducks (1.94 percent). India possesses a huge livestock population of 512 million nos. This mainly includes cattle, buffaloes, goats, sheep, and pigs. There was a decrease of 33 percent of the livestock population in India as compared to the previous census. The cattle, buffalo, sheep, goat, pig, and others contribute 37.28, 21.23, $12.71,26.4,2.01$ and 0.5 percent, respectively in total livestock population. The livestock population India has substantially increased in Gujarat (15.36 percent), Uttar Pradesh (14.01 percent), Assam (10.77 percent), Punjab (9.57 percent), Bihar (8.56 percent), Sikkim (7.96 percent), Meghalaya (7.41 percent) and Chhattisgarh (4.34 percent). Adeline has been noted in the population of cattle, sheep, goats, and pigs by $4.1,9.07,3.82$ and 7.54 percent, respectively while the population of buffalo and poultry increased by 3.19 and 19 percent, respectively in the last inter-censual period. A significant increase of 20.18 percent has been registered in the Exotic and crossbred cattle population while the indigenous cattle diminished by 8.94 percent. 729.21 million the total poultry population of India, which includes 692.65, 23.54 and 13.02 million chickens, duck and turkeys \& other poultry, respectively There is a growth trend in total poultry population quite more as compared to the total livestock population (Islam, Anjum, Modi \& Wadhwani, 2016) as per the observation.

\section{Objectives}

- Analyze the livestock population structure geographically.

- To analyze the role of livestock in balancing against risks.

- To identify the effect of modernization on livestock scenario. 


\section{Research Methodology}

The study area "Jodhpur, Barmer and Nagaur" district is quite backward in socio - economic status as it lies in Western arid Rajasthan where people are chiefly engaged in livestock occupation. This geographical study aims at analysing present scenario of livestock which has emerged as one of the key components of agriculture growth in arid region in recent years. Causal research is conducted in order to identify the extent and nature of cause-and-effect relationships.

\section{Sampling Procedure}

The present study is confined to study of secondary data for the livestock population of Barmer, Nagaur and Jodhpur districts of Rajasthan and the factors affecting livestock productivity and livestock occupation of rural people of the three districts.

\section{Data Analysis}

Table 01: Density of Livestock in Barmer, Jodhpur and Nagaur

\begin{tabular}{|l|c|c|c|c|c|c|c|c|c|c|}
\hline Year & $\begin{array}{l}\text { Area of } \\
\text { (B+J+N) }\end{array}$ & $\begin{array}{l}\text { Cattle } \\
\text { Density }\end{array}$ & $\begin{array}{l}\text { Buffalo } \\
\text { Density }\end{array}$ & $\begin{array}{l}\text { Sheep } \\
\text { Density }\end{array}$ & $\begin{array}{l}\text { Goat } \\
\text { Density }\end{array}$ & $\begin{array}{l}\text { Horses \& } \\
\text { Ponies } \\
\text { Density }\end{array}$ & $\begin{array}{l}\text { Donkey } \\
\text { Density }\end{array}$ & $\begin{array}{l}\text { Camel } \\
\text { Density }\end{array}$ & $\begin{array}{l}\text { Other } \\
\text { Density }\end{array}$ & $\begin{array}{l}\text { Total } \\
\text { Livestock } \\
\text { Density }\end{array}$ \\
\hline $\mathbf{1 9 6 1}$ & 68525.5 & 74 & 9.70 & 65 & 62 & 0.27 & 1.32 & 5.8 & 0.048 & 218 \\
\hline $\mathbf{1 9 6 6}$ & 68525.5 & 84 & 10.65 & 91 & 79 & 0.23 & 1.29 & 7.3 & 0.059 & 273 \\
\hline $\mathbf{1 9 7 2}$ & 68738 & 58 & 10.30 & 95 & 110 & 0.14 & 1.33 & 8.5 & 0.100 & 283 \\
\hline $\mathbf{1 9 7 7}$ & 68738 & 70 & 13.86 & 122 & 113 & 0.18 & 2.03 & 9.0 & 0.114 & 331 \\
\hline $\mathbf{1 9 8 3}$ & 68955 & 74 & 17.52 & 160 & 139 & 0.14 & 2.19 & 8.3 & 0.233 & 401 \\
\hline $\mathbf{1 9 8 8}$ & 68955 & 49 & 16.94 & 100 & 96 & 0.15 & 1.52 & 6.9 & 0.400 & 271 \\
\hline $\mathbf{1 9 9 2}$ & 68955 & 63 & 24.68 & 143 & 110 & 0.11 & 2.16 & 8.6 & 0.653 & 391 \\
\hline $\mathbf{1 9 9 7}$ & 68955 & 76 & 37.26 & 194 & 184 & 0.13 & 2.13 & 7.5 & 0.716 & 502 \\
\hline $\mathbf{2 0 0 3}$ & 68955 & 62 & 58.35 & 118 & 158 & 0.15 & 1.48 & 4.7 & 1.021 & 404 \\
\hline $\mathbf{2 0 0 7}$ & 68955 & 71 & 41.47 & 135 & 214 & 0.14 & 1.06 & 4.0 & 0.281 & 468 \\
\hline $\mathbf{2 0 1 2}$ & 68955 & 93 & 52.32 & 114 & 259 & 0.29 & 0.90 & 2.9 & 0.469 & 524 \\
\hline
\end{tabular}

Source: livestock census reports 1961-2012, Board of Revenue Ajmer

* Population Density of livestock = Number of Livestock/Land Area.

Table 1 shows the combined density of livestock in all the three districts taken for study viz. Barnmer, Nagaur and Jodhpur district. From above table it is quite evident that Goat density (259) and Sheep density (114) are highest followed by cattle density at the third place. We have already seen in the separate analysis of livestock densities of the three districts that goat, cattle and sheep are the highly maintained live stocks in the three districts. Also from the table it is clear that total livestock density from 1961 to 2012 is mainly increasing with only two declines noticed in the year 1988 and 2003. Thus the total livestock is witnessing an increase during the time period under consideration. To find the significance growth of livestock population in Barmer, Jodhpur and Nagaur districts during the period of 1961 to 2012 following hypothesis has been formulated and tested with the help of regression analysis.

\begin{tabular}{|l|l|}
\hline $\mathrm{H}_{01}:-$ & $\begin{array}{l}\text { There is no significant growth of Livestock population in Barmer, Jodhpur and } \\
\text { Nagaur district during the period of } 1961 \text { to } 2012 .\end{array}$ \\
\hline $\mathrm{H}_{1}:-$ & $\begin{array}{l}\text { There is a significant growth of Livestock population in Barmer, Jodhpur and Nagaur } \\
\text { district during the period of } 1961 \text { to } 2012 .\end{array}$ \\
\hline
\end{tabular}

Table 02: Statistics for Livestock in Barmer, Jodhpur and Nagaur

\begin{tabular}{|l|c|c|c|c|}
\hline Category & N & Mean & Std. Deviation & Std. Error Mean \\
\hline Cattle & 11 & 70.36 & 12.209 & 3.681 \\
\hline Buffalos & 11 & 26.64 & 17.753 & 5.353 \\
\hline Sheep & 11 & 121.55 & 35.691 & 10.761 \\
\hline Goat & 11 & 138.55 & 60.120 & 18.127 \\
\hline Horses \& Ponies & 11 & .18 & .060 & .018 \\
\hline Donkey & 11 & 1.58 & .466 & .141 \\
\hline Camel & 11 & 6.68 & 2.056 & .620 \\
\hline Other & 11 & .37 & .316 & .095 \\
\hline Total & 11 & 369.6364 & 102.32524 & 30.85222 \\
\hline
\end{tabular}

Source: calculated by author 
Table 2 presented the mean, standard deviation with standard error mean has been given in the table. Table above depicts that the mean score value of the Cattle $(70.36 \pm$ 12.209), Buffalos (26.64 \pm 17.753$)$, Sheep (121.55 \pm 35.691$)$, Goat (138.55 \pm 60.12$)$, Horses \& Ponies (0.18 \pm 0.06$)$, Donkey (1.58 \pm 0.466$)$, Camel $(6.68 \pm 2.056)$, other $(0.37 \pm 0.316)$ and Total (369.6364 \pm 102.32524$)$.

Table 03: Regression for Livestock in Barmer, Nagaur and Jodhpur

\begin{tabular}{|c|c|c|c|c|c|c|}
\hline \multicolumn{7}{|c|}{ ANOVA $^{a}$} \\
\hline \multicolumn{2}{|c|}{ Model } & $\begin{array}{c}\text { Sum of } \\
\text { Squares }\end{array}$ & $\mathrm{Df}$ & Mean Square & $F$ & Sig. \\
\hline \multirow[t]{3}{*}{1} & Regression & 2789.383 & 9 & 309.931 & 4.104 & $.0367^{b}$ \\
\hline & Residual & 75.526 & 1 & 75.526 & & \\
\hline & Total & 2864.909 & 10 & & & \\
\hline \multicolumn{7}{|c|}{ a. Dependent Variable: Year } \\
\hline
\end{tabular}

Source: calculated by author

Table 3 indicates that the regression model predicts the dependent variable significantly well. Here, $p=.03367$, which is less than 0.05 , and indicates that, overall, the regression model statistically significantly predicts the outcome variable (i.e., it is a good fit for the data). The Coefficients table provides us with the necessary information to predict livestock from year, as well as determine whether livestock contributes statistically significantly to the model (by looking at the "Sig." column). The significant value is less than 0.05 ( $p$ value). This means we have to reject the null hypothesis and accept the alternative hypothesis that there is a significant growth of Livestock population in Barmer, Nagaur and Jodhpur district during the period of 1961 to 2012. Thus during last 5 decades livestock has grown up to a significant level due to the combined efforts made by government and rural people. To find the trend line equations and predicted values and also for their regression analysis following table and graphs are used;

Table 04: Trend Line Equation and Predicted Value of Cattle in Barmer, Jodhpur and Nagaur

\begin{tabular}{|c|c|c|c|}
\hline Year & Area of $\mathbf{B + J + N}$ & Cattle Density & Predicted Values $\mathbf{( Y = 0 . 0 8 2 6 \mathbf { ~ } \mathbf { - 9 3 . 7 6 6 5 2 } )}$ \\
\hline 1961 & 68525.5 & 74 & 68.212 \\
\hline 1966 & 68525.5 & 84 & 68.625 \\
\hline 1972 & 68738 & 58 & 69.121 \\
\hline 1977 & 68738 & 70 & 69.534 \\
\hline 1983 & 68955 & 74 & 70.029 \\
\hline 1988 & 68955 & 49 & 70.442 \\
\hline 1992 & 68955 & 63 & 70.773 \\
\hline 1997 & 68955 & 76 & 71.186 \\
\hline 2003 & 68955 & 62 & 71.681 \\
\hline 2007 & 68955 & 71 & 72.012 \\
\hline 2012 & 68955 & 93 & 72.425 \\
\hline
\end{tabular}

Source: Livestock census reports 1961-2012, Board of Revenue, Ajmer

Above table represents the cattle density for years ranging from period of 1961 to 2012 , the cattle population of Barmer, Nagaur and Jodhpur district along with its corresponding predicted value is also shown. The predicated value is calculated on the basis of following trend line equation;

\section{$\mathrm{Y}=0.0826 \mathrm{X}-93.76652$}

Where $\mathrm{Y}=$ predicted value and $\mathrm{X}=$ year

A trend line is a line drawn on a chart based on data points on the chart and which helps to determine a trend and help make trading decisions. Trend lines are commonly used to decide entry and exit timing when trading securities. Trend lines are an important tool in technical analysis for both trend identification and confirmation. It is a straight line that connects two or more variable points and then extends into the future to act as a line of support or resistance.

\section{Uptrend Line}

An uptrend line displays a positive slope and is formed simply by joining two or more low points. To have a positive slope the second low must be higher than the first one for a 
line to have a positive slope. Uptrend lines act as support and indicate that net-increase (increase in livestock) is increasing even as the year wise distribution displaying fluctuations.

\section{Downtrend Line}

A downtrend line shows a negative slope and is formed merely by joining two or more high points. Here in this case the second high must be lower than the first for the line to have a negative slope. Downtrend lines act as resistance, and indicate that net-increase (increase in livestock) is decreasing even as the time increasing.

\section{Graph 01: Trend Line Equation and Predicted Value of Cattle in Barmer, Jodhpur and Nagaur}

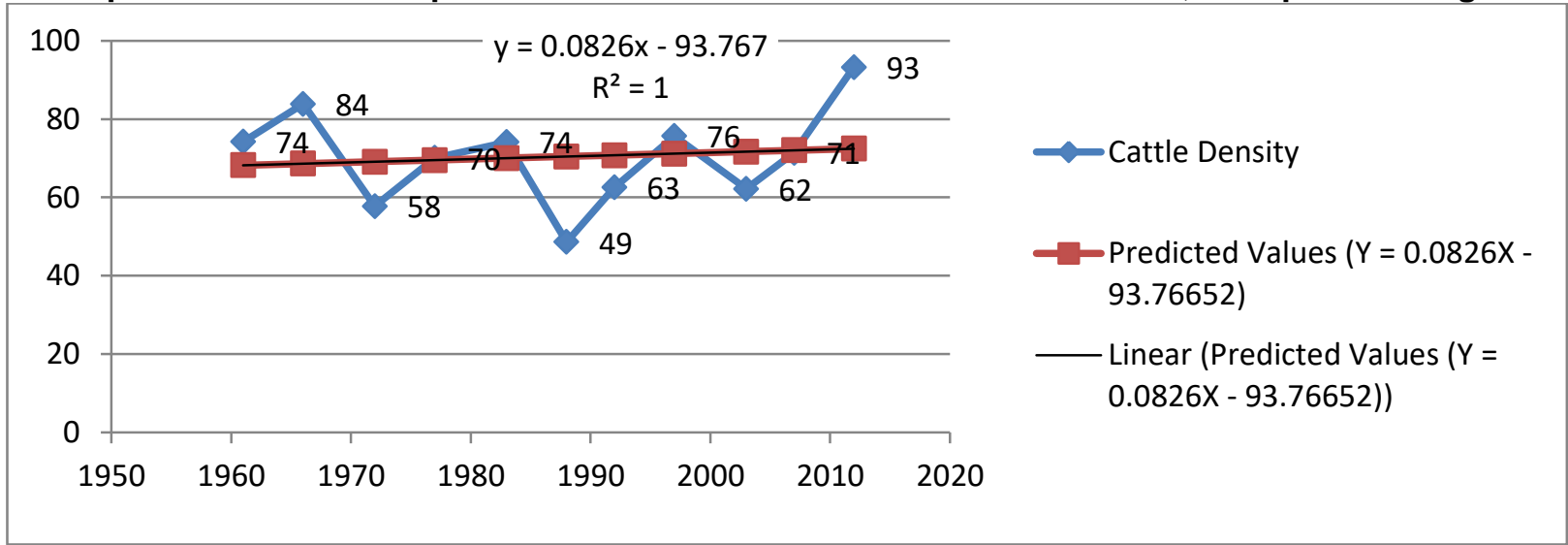

Source: Calculated by author

R-squared is a statistical measure of how close the data are to the fitted trend line. Just by looking at the regression line running up through the data, predictions can be done. For 2012, it looks like the line will be somewhere between 80 and 100 cattle density! That might be "good enough", but regression also gives a useful equation, which for this chart is: $\mathrm{Y}=0.0826 \mathrm{X}-93.76652$

What that means is, we can plug in an $x$ value (the year) and get a pretty good estimate of cattle density for any year. For example, 2007:

$\mathrm{Y}=\mathbf{0 . 0 8 2 6 ( 2 0 0 7 )} \mathbf{- 9 3 . 7 6 6 5 2}=74.018$ density, which is exactly same as the actual figure of 72.012 cattle density for that year.

Best of all, we can use the equation to make predictions. For example, how much cattle density will grow in 2017 ?

$Y=\mathbf{0 . 0 8 2 6 ( 2 0 1 7 )}-\mathbf{9 3 . 7 6 6 5 2}=93.76$ cattle density .

Regression also gives an $\mathrm{R}$ squared value, which for this graph is 1 . This number tells how good the model is. The values range from 0 to 1 , with 0 being a terrible model and 1 being a perfect model. As it can be probably seen, 1 is a fairly an excellent model so it can be fairly confident in cattle density prediction!

Furthermore the trend line here has a positive slope showing an uptrend line but with a very little slope displaying very less increase in net cattle density value for the course of time and an increase in this value can also be predicted for the future. Thus to make the increment in density significant combined effort needs to be made by the govt. as well as rural people. Also it can be easily interpreted from the graph that cattle density is witnessing regular fluctuations. From 1961 to 2012 cattle density can be viewed as fluctuating due to the vulnerable climatic conditions of Barmer, Nagaur and Jodhpur districts. Regression also gives an $R$ squared value, which for this graph is 1 . This number tells how good the model is. The values range from 0 to 1 , with 0 being a terrible model and 1 being a perfect model. As it can probably be viewed, 1 is a fairly an excellent model so it can be fairly confident in total livestock density prediction. Results show the combined density of livestock in all the three districts taken for study viz. Barmer, Nagaur and Jodhpur districts that Goat density and Sheep density are highest followed by cattle density at the third place. Additionally the trend line for total livestock has a positive slope showing an uptrend line displaying increase in net total livestock density value for the course of time and also for the future. Also it can be viewed from the graph 
that total livestock density in Barmer, Nagaur and Jodhpur district from the year 1961 to 2012 is on an increasing trend with the lowest density recorded in the year 1988 and 2003.

\section{Conclusion}

The study of Changing Livestock scenario in Jodhpur, Barmer and Nagaur districts was proved as important as Rajasthan is the largest state of India gifted with big livestock production and the significance of agriculture and allied sector in the state gross domestic product is considerably higher. Livestock was thus successfully proved to be life saviour in much distress, especially in case of drought in the study area. Livestock provides a potentially significant source of diversified income to smallholder operating in the difficult climatic condition in the three districts under observation. Through this study significance and development of livestock and specific approaches for the growth of the livestock were identified.

\section{References}

1. $19^{\text {th }}$ Indian livestock census All India Summery Report (2013) Govt. of India Ministry of agriculture department of Animal husbandry and dairying - New Delhi.

2. Abhichandani and Ghosh, P.K. (1986) "Animal husbandry in Arid zone environment In: Desert environment conservation and management (Ed.) - CAZRI

3. Annual Report 2012-13 Department of animal husbandry dairying and fisheries ministry of agriculture, Govt .of India - New Delhi.

4. Annual Report. (2011-12) Department of Animal Husbandry, Dairying, and Fisheries. Ministry of Agriculture, Govt. of India, New Delhi. (http://www.ijset.net/journal/956.pdf)

5. Baba, S.H., Wani, M.H. and Zargar, B.A. (2011) Dynamics and sustainability of the livestock sector in Jammu \& Kashmir., Agric. Econ. Res. Rev., 24: 119-132

6. Census Reports of Barmer, Jodhpur and Nagaur District 2012

7. Chander, M., Kumar, S., Rathore, R. S., Mukherjee, R., Kondaiah, N., \& Pandey, H. N. (2007) Organic vis-a-vis Conventional livestock production potential in India. In Papers submitted to the International Conference on Organic Agriculture and Food Security, FAO, Rome, Italy (pp. 48-49).

8. Gupta, Shweta- Livestock Revolution in India: Issues and Impacts on Small Scale Producers

9. http://animalhusbandry.rajasthan.gov.in/livestock_census.aspx

10. https://www.researchgate.net

11. Islam, M. M., Anjum, S., Modi, R. J., \& Wadhwani, K. N. (2016) The scenario of livestock and poultry in India and their contribution to the national economy. International Journal of Science, Environment and Technology, 5(3), 956-65.

12. Kohler-Rollefson, I. (2001) The livestock revolution and organic animal husbandry. EcolFmg, 27, 10-11.

13. Kumar, A. (2010) Exports of Livestock Products from India: Performance, Competitiveness, and Determinants. Agricultural Economics Research Review, 23(1).

14. National Accounts Division. Central Statistical Office. Ministry of statistics and programme implementation.

15. Prabhu, M., Kumar, G. S., Pandian, A., Selvakumar, K. N., \& Jayavarathan, B. (2012) Dynamics of livestock population-India vis-à-vis Tamil Nadu.

16. Raut, K. C. (2006) Research Priorities in Livestock Statistics. J. Ind. Soc. Agril. Statist, 60(1), 16-26.

17. Soju, S., \& Meena, G. L. (2017) Dynamics of livestock population and output in Rajasthan: A temporal analysis. Journal of Animal Research, 7(2), 345. 